\title{
Comparison of Power Distribution, Losses and Efficiencies of a Steam Turbine with and without Extractions
}

\author{
Vedran Mrzljak*, Sandi Baressi Šegota, Hrvoje Meštrić, Zlatan Car
}

\begin{abstract}
The paper presents an analysis of two steam turbine operation regimes - regime with all steam extractions opened (base process) and regime with all steam extractions closed. Closing of all steam extractions significantly increases turbine real developed power for $5215.88 \mathrm{~kW}$ and increases turbine energy and exergy losses with simultaneous decrease of turbine energy and exergy efficiencies for more than $2 \%$. First extracted steam mass flow rate has a dominant influence on turbine power losses (in comparison to turbine maximum power when all of steam extractions are closed). Cumulative power losses caused by steam mass flow rate extractions are the highest in the fourth turbine segment and equal to $1687.82 \mathrm{~kW}$.
\end{abstract}

Keywords: efficiencies; losses; power distribution; steam extractions; steam turbine

\section{INTRODUCTION}

Steam turbines are integral components of steam power plants of any kind (land based [1-3] or marine steam power plants $[4,5])$. In the most of the cases its main function is electricity production (or ship propulsion in marine steam power plants) $[6,7]$.

In marine propulsion, new complex propulsion systems are completely or at least partially based on steam turbine processes [8]. Steam turbine processes are also inevitable components of combined [9-11], cogeneration [12, 13] or multi-generation power systems $[14,15]$.

In various power systems, low power steam turbines are also used for several auxiliary purposes (for pumps drive [16, 17], for the drive of additional (or main) electrical generators [18], etc.). It should be noted that such auxiliary steam turbines usually did not possess any steam extractions [19].

Along with the production of electricity (or ship propulsion) the purpose of the main steam turbine in any system is to provide a sufficient steam mass flow rate for condensate/feed water heating (at condensate/feed water return line from the steam condenser to steam generator) $[20$, 21].

In this paper, the analysis of steam turbine with nominal power of $66 \mathrm{MW}$ is presented. Two possible steam turbine operation regimes were investigated: operation regime with all steam extractions opened (base process) and operation regime when the all steam extractions are closed. Obtained results suggest that closing of steam extractions significantly increases turbine developed power, but simultaneously it increases turbine energy and exergy losses and decreases turbine energy and exergy efficiencies. Cumulative turbine power losses and turbine power losses in each turbine segment caused by steam extractions are calculated and discussed.

\section{CHARACTERISTICS AND OPERATING PROCESS OF THE ANALYZED STEAM TURBINE}

The analyzed steam turbine has a nominal power of 66 MW and operates in Al-Hussein power plant in Jordan [22]. For proper turbine analysis, it is important to know the steam mass flow rate as well as steam pressure and temperature at the turbine inlet, outlet and at each turbine extraction [23]. Steam turbine scheme and necessary operating points required for the performed analysis are presented in Fig. 1.

Superheated steam at the turbine inlet is delivered to the analyzed turbine direct from the steam generator [24-26], Fig. 1. At each steam turbine extraction, a certain steam mass flow rate was lead to regenerative condensate/feed water heating system (in this power plant regenerative condensate/feed water heating system consists of two lowpressure condensate heaters [27, 28], deaerator [29] and two high-pressure feed water heaters [30, 31]). After expansion in the analyzed turbine, remaining steam mass flow rate is delivered to steam condenser [32, 33].

Unlike most other conventional steam power plants, where the steam condenser is cooled with water [34, 35], in this power plant condenser is cooled with air. Steam condenser air cooling enables that steam, after expansion in the analyzed steam turbine - operating point 7, Fig. 1 and Fig. 2, is still superheated (not saturated as usual) $[36,37]$. Air cooling performs additional cooling of superheated steam and enable its condensation.

Numerical analyses (energy and exergy analyses) performed in this paper do not require knowledge of the steam turbine or any other steam system component's internal structure [38-40]. Those methods are widely used in the analyses of various steam turbines [41, 42], gas turbines [43] and the entire power plants [44, 45] (black box methods).

It should be noted that in Fig. 1 the numeration of condensate/feed water heaters (water heaters) is arranged from steam condenser to steam generator (water heater mounted closer to steam condenser has lower number). 


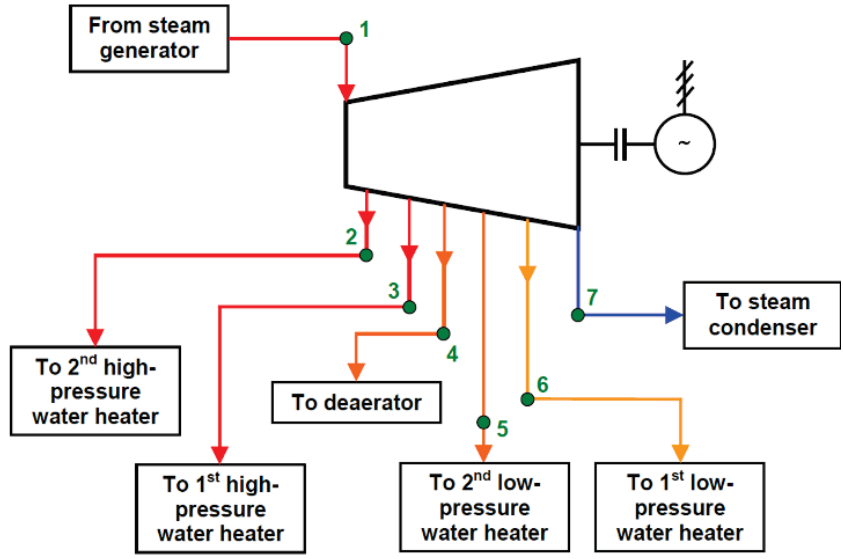

Figure 1 Scheme of the analyzed steam turbine with steam extractions along with marked operating points required for the analysis

Steam expansion processes inside the analyzed turbine in $h$-s (specific enthalpy-specific entropy) diagram are shown in Fig. 2. Real (polytropic) steam expansion process is presented with operating points from 1 to 7 - dark red curve (according to Fig. 1). Ideal (isentropic) steam expansion process is presented with operating points from 1 to 7 - blue line. Ideal (isentropic) steam expansion process assumes that steam specific entropy during the whole expansion process remains the same as at the beginning of the expansion (as in operating point 1) [46]. Steam mass flow rates extracted from the analyzed turbine are marked with red arrows.

Proper energy analysis of any steam turbine, as well as of turbine analyzed in this paper, requires comparison of real (polytropic) and ideal (isentropic) steam expansion processes [47], while the exergy analysis of any steam turbine requires only the real (polytropic) steam expansion process [48, 49].

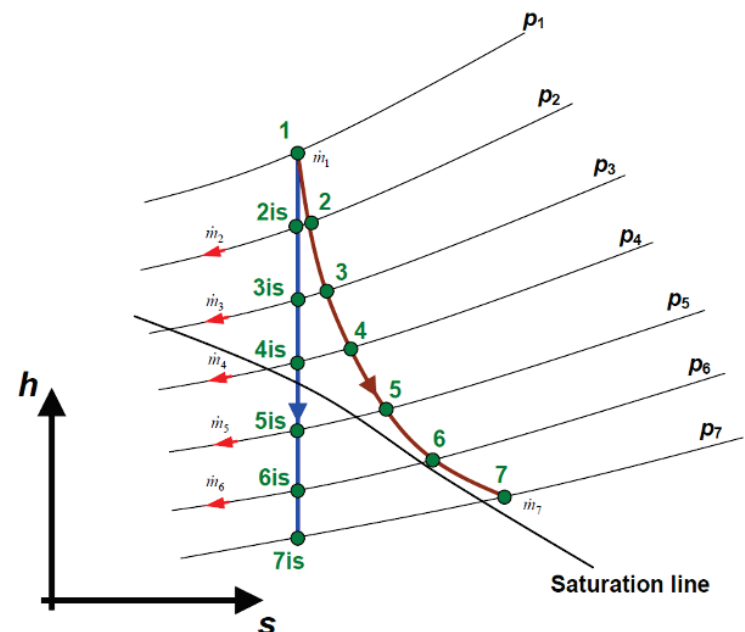

Figure 2 Ideal (isentropic) and real (polytropic) steam expansion processes inside the analyzed turbine in $h$-s diagram

\section{EQUATIONS REQUIRED FOR THE COMPARISON OF STEAM TURBINE PROCESSES WITH AND WITHOUT EXTRACTIONS}

All the equations for the steam turbine analysis in this paper are presented according to operating points from Fig. 1 and according to turbine expansion processes (ideal and real) from Fig. 2.

Real (polytropic) power of the analyzed steam turbine for the process with steam extractions is:

$P_{\mathrm{RE}, \mathrm{WSE}}=\dot{m}_{1} \cdot\left(h_{1}-h_{2}\right)+\left(\dot{m}_{1}-\dot{m}_{2}\right) \cdot\left(h_{2}-h_{3}\right)+\left(\dot{m}_{1}-\dot{m}_{2}-\dot{m}_{3}\right) \cdot$

$\left(h_{3}-h_{4}\right)+\left(\dot{m}_{1}-\dot{m}_{2}-\dot{m}_{3}-\dot{m}_{4}\right) \cdot\left(h_{4}-h_{5}\right)+\left(\dot{m}_{1}-\dot{m}_{2}-\dot{m}_{3}-\dot{m}_{4}-\dot{m}_{5}\right) \cdot$

$\left(h_{5}-h_{6}\right)+\left(\dot{m}_{1}-\dot{m}_{2}-\dot{m}_{3}-\dot{m}_{4}-\dot{m}_{5}-\dot{m}_{6}\right) \cdot\left(h_{6}-h_{7}\right)$,

while for the turbine process without steam extractions (entire steam mass flow rate at the turbine inlet expanded through the turbine), real (polytropic) power is:

$P_{\mathrm{RE}, \mathrm{WOSE}}=\dot{m}_{1} \cdot\left(h_{1}-h_{7}\right)$.

Ideal (isentropic) power of the analyzed steam turbine for the process with steam extractions is:

$P_{\mathrm{ID}, \mathrm{WSE}}=\dot{m}_{1} \cdot\left(h_{1}-h_{2 \mathrm{is}}\right)+\left(\dot{m}_{1}-\dot{m}_{2}\right) \cdot\left(h_{2 \mathrm{is}}-h_{3 \mathrm{is}}\right)+\left(\dot{m}_{1}-\dot{m}_{2}-\dot{m}_{3}\right) \cdot$

$\left(h_{3 \mathrm{is}}-h_{4 \mathrm{is}}\right)+\left(\dot{m}_{1}-\dot{m}_{2}-\dot{m}_{3}-\dot{m}_{4}\right) \cdot\left(h_{4 \mathrm{is}}-h_{5 \mathrm{is}}\right)+$

$\left(\dot{m}_{1}-\dot{m}_{2}-\dot{m}_{3}-\dot{m}_{4}-\dot{m}_{5}\right) \cdot\left(h_{5 \mathrm{si}}-h_{6 \mathrm{is}}\right)+$

$\left(\dot{m}_{1}-\dot{m}_{2}-\dot{m}_{3}-\dot{m}_{4}-\dot{m}_{5}-\dot{m}_{6}\right) \cdot\left(h_{6 \mathrm{is}}-h_{7 \mathrm{is}}\right)$

while for the turbine process without steam extractions, ideal (isentropic) power is:

$P_{\mathrm{ID}, \mathrm{WOSE}}=\dot{m}_{1} \cdot\left(h_{1}-h_{7 \mathrm{is}}\right)$.

Energy losses of the analyzed steam turbine for the process with steam extractions are:

$\dot{E}_{\mathrm{en}, \mathrm{LOSS}, \mathrm{WSE}}=P_{\mathrm{ID}, \mathrm{WSE}}-P_{\mathrm{RE}, \mathrm{WSE}}$,

while for the turbine process without steam extractions, energy losses are:

$\dot{E}_{\text {en,LOSS,WOSE }}=P_{\mathrm{ID}, \mathrm{WOSE}}-P_{\mathrm{RE}, \mathrm{WOSE}}$.

The exergy power of any fluid flow ( $i=$ index of each operating point from Fig. 1 or Fig. 2) is calculated according to $[50,51]$ as:

$\dot{E} x_{\mathrm{i}}=\dot{m}_{\mathrm{i}} \cdot e x_{\mathrm{i}}$

In the Eq. (7) $e x_{\mathrm{i}}$ is fluid flow specific exergy (for each operating point from Fig. 1 or Fig. 2). Fluid flow specific exergy is calculated according to $[52,53]$ as:

$e x_{\mathrm{i}}=\left(h_{\mathrm{i}}-h_{0}\right)-T_{0} \cdot\left(s_{\mathrm{i}}-s_{0}\right)$.

Conditions of the ambient for the calculation of fluid flow specific exergy in each operating point ( 0 is the index of the ambient conditions) are ambient temperature of 298.15 $\mathrm{K}$ and ambient pressure of $0.1013 \mathrm{MPa}$, as proposed in the literature $[22,54]$.

Exergy losses of the analyzed steam turbine for the process with steam extractions are: 
$\dot{E}_{\text {ex,LOSS,WSE }}=\dot{E} x_{1}-\dot{E} x_{2}-\dot{E} x_{3}-\dot{E} x_{4}-\dot{E} x_{5}-\dot{E} x_{6}-\dot{E} x_{7}-P_{\mathrm{RE}, \mathrm{WSE}}$,

while for the turbine process without steam extractions, exergy losses are:

$\dot{E}_{\text {ex,LOSS,WOSE }}=\dot{E} x_{1}-\dot{m}_{1} \cdot e x_{7}-P_{\mathrm{RE}, \mathrm{WOSE}}$.

The energy efficiency of the analyzed steam turbine for the process with steam extractions is:

$\eta_{\mathrm{en}, \mathrm{WSE}}=\frac{P_{\mathrm{RE}, \mathrm{WSE}}}{P_{\mathrm{ID}, \mathrm{WSE}}}$

while for the turbine process without steam extractions, energy efficiency is:

$\eta_{\mathrm{en}, \mathrm{WOSE}}=\frac{P_{\mathrm{RE}, \mathrm{WOSE}}}{P_{\mathrm{ID}, \mathrm{WOSE}}}$

The exergy efficiency of the analyzed steam turbine for the process with steam extractions, according to [55] is:

$\eta_{\mathrm{ex}, \mathrm{WSE}}=\frac{P_{\mathrm{RE}, \mathrm{WSE}}}{\dot{E} x_{1}-\dot{E} x_{2}-\dot{E} x_{3}-\dot{E} x_{4}-\dot{E} x_{5}-\dot{E} x_{6}-\dot{E} x_{7}}$,

while for the turbine process without steam extractions, exergy efficiency is:

$\eta_{\mathrm{ex}, \mathrm{WOSE}}=\frac{P_{\mathrm{RE}, \mathrm{WOSE}}}{\dot{E} x_{1}-\dot{m}_{1} \cdot e x_{7}}$.

Each steam mass flow rate extracted from the turbine does not expand throughout the whole turbine. When compared with the same turbine without steam extractions, each extracted steam mass flow rate causes turbine power losses and reduces turbine maximum power. For each extracted steam mass flow rate turbine power losses (cumulative power losses and power losses for each turbine segment) can be calculated with regard to turbine maximum power. Analyzed turbine is divided into six segments (one turbine segment is defined between each two consecutive operating points from Fig. 1 and Fig. 2).

Cumulative turbine power losses for each extracted steam mass flow rate and for the real (polytropic) steam expansion are calculated, according to Fig. 1 and Fig. 2, as:

-Turbine cumulative power losses for the first extracted steam mass flow rate $\left(\dot{m}_{2}\right)$ :

$$
\begin{aligned}
P_{\text {LOSS }, \mathrm{RE}, \mathrm{m} 2}= & \dot{m}_{2} \cdot\left(h_{2}-h_{3}\right)+\dot{m}_{2} \cdot\left(h_{3}-h_{4}\right)+\dot{m}_{2} \cdot\left(h_{4}-h_{5}\right)+ \\
& \dot{m}_{2} \cdot\left(h_{5}-h_{6}\right)+\dot{m}_{2} \cdot\left(h_{6}-h_{7}\right) .
\end{aligned}
$$

-Turbine cumulative power losses for the second extracted steam mass flow rate $\left(\dot{m}_{3}\right)$ :

$$
\begin{aligned}
P_{\text {LOSS }, \mathrm{RE}, \mathrm{m} 3}= & \dot{m}_{3} \cdot\left(h_{3}-h_{4}\right)+\dot{m}_{3} \cdot\left(h_{4}-h_{5}\right)+\dot{m}_{3} \cdot\left(h_{5}-h_{6}\right)+ \\
& \dot{m}_{3} \cdot\left(h_{6}-h_{7}\right) .
\end{aligned}
$$

-Turbine cumulative power losses for the third extracted steam mass flow rate $\left(\dot{m}_{4}\right)$ :

$P_{\text {LOSS,RE,m } 4}=\dot{m}_{4} \cdot\left(h_{4}-h_{5}\right)+\dot{m}_{4} \cdot\left(h_{5}-h_{6}\right)+\dot{m}_{4} \cdot\left(h_{6}-h_{7}\right)$.

-Turbine cumulative power losses for the fourth extracted steam mass flow rate $\left(\dot{m}_{5}\right)$ :

$P_{\mathrm{LOSS}, \mathrm{RE}, \mathrm{m} 5}=\dot{m}_{5} \cdot\left(h_{5}-h_{6}\right)+\dot{m}_{5} \cdot\left(h_{6}-h_{7}\right)$.

-Turbine cumulative power losses for the fifth extracted steam mass flow rate $\left(\dot{m}_{6}\right)$ :

$P_{\text {LOSS }, \mathrm{RE}, \mathrm{m} 6}=\dot{m}_{6} \cdot\left(h_{6}-h_{7}\right)$.

Cumulative turbine power losses for each extracted steam mass flow rate and for the ideal (isentropic) steam expansion are calculated by using the same equations from Eq. (15) to Eq. (19) with a note that steam specific enthalpies must be taken for the same operating points but for ideal (isentropic) expansion process, Fig. 2. Steam mass flow rates extracted in each turbine extraction remain the same for real and ideal steam expansion processes.

\section{DATA FOR THE OBSERVED STEAM TURBINE ANALYSIS}

Analysis of the observed steam turbine requires knowing the steam temperature, pressure and mass flow rate in each turbine operating point from Fig. 1 and Fig. 2. Such steam operating data were found in [22] and presented in Tab. 1. Mentioned data were obtained by measurements during turbine exploitation, therefore, they represent operating parameters of real (polytropic) steam expansion process. For each turbine operating point steam specific enthalpy, specific entropy and specific exergy were calculated by using NIST REFPROP 9.0 software [56], which are also presented in Tab. 1.

Table 1 Data for each steam turbine operating point (base process) [22]

\begin{tabular}{|c|c|c|c|c|c|c|}
\hline O.P.* & $\begin{array}{c}\text { Temperature } \\
(\mathrm{K})\end{array}$ & $\begin{array}{c}\text { Pressure } \\
(\mathrm{MPa})\end{array}$ & $\begin{array}{c}\text { Steam } \\
\text { mass } \\
\text { flow rate } \\
(\mathrm{kg} / \mathrm{s})\end{array}$ & $\begin{array}{c}\text { Steam } \\
\text { specific } \\
\text { enthalpy } \\
(\mathrm{kJ} / \mathrm{kg})\end{array}$ & $\begin{array}{c}\text { Steam } \\
\text { specific } \\
\text { entropy } \\
(\mathrm{kJ} / \mathrm{kg} \cdot \mathrm{K})\end{array}$ & $\begin{array}{c}\text { Steam } \\
\text { specific } \\
\text { exergy } \\
(\mathrm{kJ} / \mathrm{kg})\end{array}$ \\
\hline 1 & 793.15 & 9.1233 & 76.389 & 3436.3 & 6.7168 & 1438.25 \\
\hline 2 & 618.55 & 2.4231 & 4.944 & 3118.1 & 6.8419 & 1082.75 \\
\hline 3 & 547.85 & 1.3244 & 4.144 & 2986.9 & 6.8835 & 939.15 \\
\hline 4 & 463.65 & 0.5690 & 4.556 & 2831.4 & 6.9511 & 763.49 \\
\hline 5 & 394.35 & 0.2060 & 3.878 & 2707.7 & 7.1173 & 590.24 \\
\hline 6 & 360.45 & 0.0628 & 1.775 & 2655.2 & 7.5169 & 418.60 \\
\hline 7 & 343.15 & 0.0272 & 57.092 & 2626.9 & 7.8193 & 300.14 \\
\hline
\end{tabular}

${ }^{*}$ O.P. = Operating Point (according to Fig. 1 and Fig. 2)

For the ideal (isentropic) steam expansion process, all the required operating parameters were calculated by knowing the steam pressure in each operating point from Fig. 1 and Fig. 2 (Tab. 1) as well as by knowing always the same steam specific entropy during ideal expansion through the turbine. 


\section{THE RESULTS OF THE STEAM TURBINE ANALYSIS AND COMPARISON OF ITS PROCESSES}

Steam turbine real (polytropic) and ideal (isentropic) power with and without steam extractions are presented in Fig. 3. Steam extractions closing significantly increases real turbine power (for $5215.88 \mathrm{~kW}$ ) and simultaneously increases ideal (isentropic) turbine power for $10117.61 \mathrm{~kW}$.

Along with the turbine power increase, closing of all steam extractions simultaneously increases analyzed turbine energy and exergy losses - energy losses increase for 4901.73 kW while exergy losses increase for 4748.09 kW, Fig. 3. Therefore, closing of all steam turbine extractions has a higher influence on turbine energy losses, which increase is higher in comparison to exergy losses.

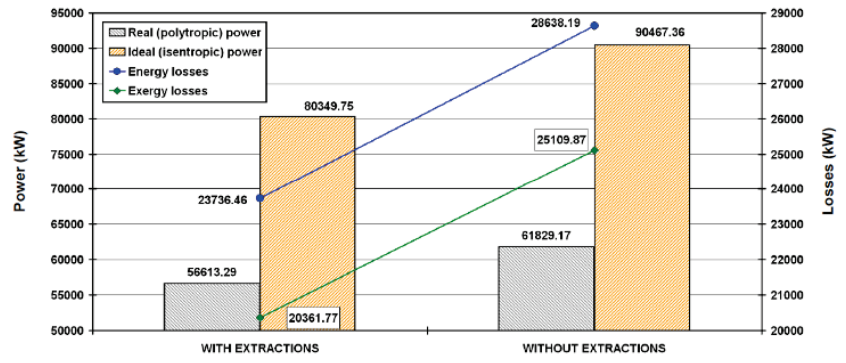

Figure 3 Change in developed power and losses of the analyzed turbine with and without steam extractions

Base turbine operation (when all steam extractions are open) results with turbine energy efficiency of $70.46 \%$ and turbine exergy efficiency of $73.55 \%$, Fig. 4. Closing of all steam extractions resulted in a decrease in both efficiencies turbine energy efficiency decreases for $2.11 \%$, while turbine exergy efficiency decreases for $2.43 \%$. From the obtained results it can also be concluded that closing of all steam extractions has a higher influence on the turbine exergy efficiency decrease (in comparison to turbine energy efficiency decrease).

Finally, regarding the analyzed turbine it can be concluded that closing of all steam extractions significantly increases turbine power (ideal or real power, Fig. 3), but simultaneously increases turbine energy and exergy losses and decreases turbine energy and exergy efficiencies, Fig. 4.

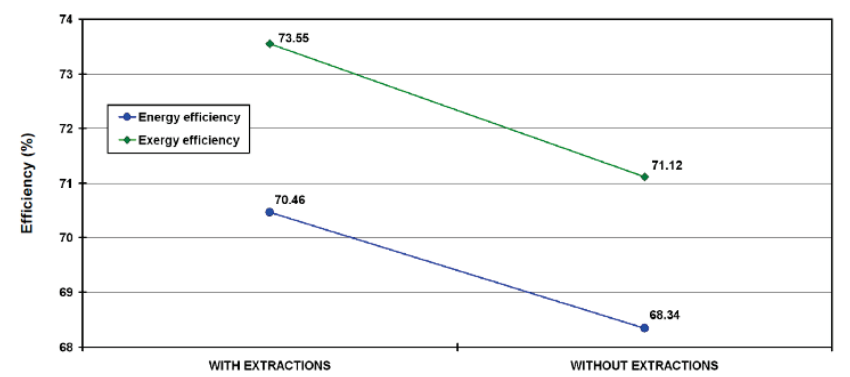

Figure 4 Change in energy and exergy efficiency of the analyzed turbine with and without steam extractions

Each steam mass flow rate extraction from the analyzed turbine (base process) participates in the reduction of maximum real or ideal turbine power. Maximum real or ideal power, which can be developed with the same steam operating parameters at the turbine inlet and outlet (operating points 1 and 7, Tab. 1) without any steam mass flow rate extraction, is presented in Fig. 3 and equal to $61829.17 \mathrm{~kW}$ for real (polytropic) steam expansion and $90467.36 \mathrm{~kW}$ for ideal (isentropic) steam expansion.

Each steam mass flow rate extracted from the analyzed turbine will expand throughout the whole turbine (to the pressure at the turbine outlet) if steam extractions were closed. Therefore, each extracted steam mass flow rate causes turbine power losses which are calculated by using equations from Eq. (15) to Eq. (19) and which are presented in Fig. 5. Power losses are the highest for the first extracted steam mass flow rate from the turbine $\left(\dot{m}_{2}\right)$, regardless of the fact whether the steam expansion is ideal or real - Fig. 2, because of the highest pressure differences between which that steam mass flow rate can expand. Following the above, power losses (again, both real and ideal) are the lowest for the last extracted steam mass flow rate $\left(\dot{m}_{6}\right)$, Fig. 5 .

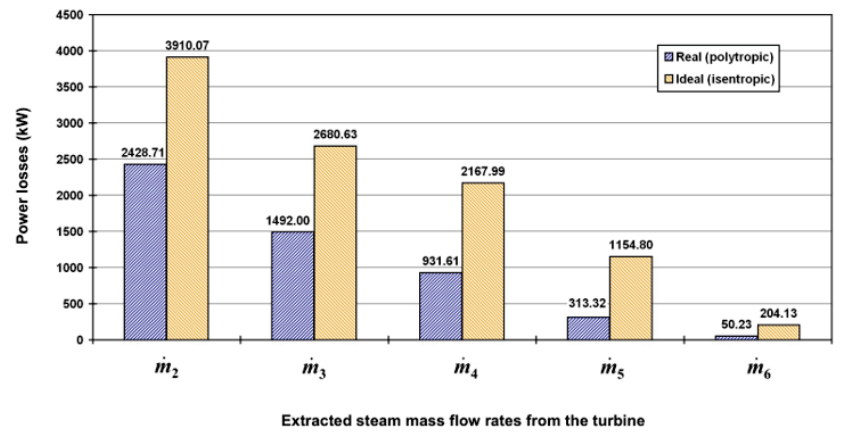

Figure 5 Real (polytropic) and ideal (isentropic) power losses due to steam mass flow rate extractions from the analyzed turbine

Analyzed turbine is divided into the segments and each turbine segment is defined between turbine operating points presented in Fig. 1 and Fig. 2. Therefore, analyzed turbine has six segments. In each turbine segment developed turbine power is calculated with and without steam extractions as well as cumulative power losses from all extracted steam mass flow rates, Fig. 6.

As can be seen from Fig. 6, in the first turbine segment developed turbine power with and without steam extractions is the same (because in the first turbine segment the entire steam mass flow rate which enter in the turbine expands). In all the other analyzed turbine segments developed turbine power without extractions is higher than power with steam extractions. In any case, the first turbine segment develops the highest, while the last turbine segment develops the lowest power.

The difference between turbine power with and without steam extractions in each turbine segment represents cumulative power losses caused by steam extractions. It can be seen from Fig. 6 that cumulative power losses caused by steam extractions are the highest in the fourth turbine segment and equal to $1687.82 \mathrm{~kW}$.

Cumulative power losses caused by steam extractions in each turbine segment are the sum of power losses from each extracted steam mass flow rate. Distribution of power losses 
on each extracted steam mass flow rate in any turbine segment is presented in Fig. 7. Power losses in the first turbine segment are not shown in Fig. 7, because the first turbine segment does not contain any steam extraction, so power losses on the first turbine segment are equal to zero, Fig. 6.

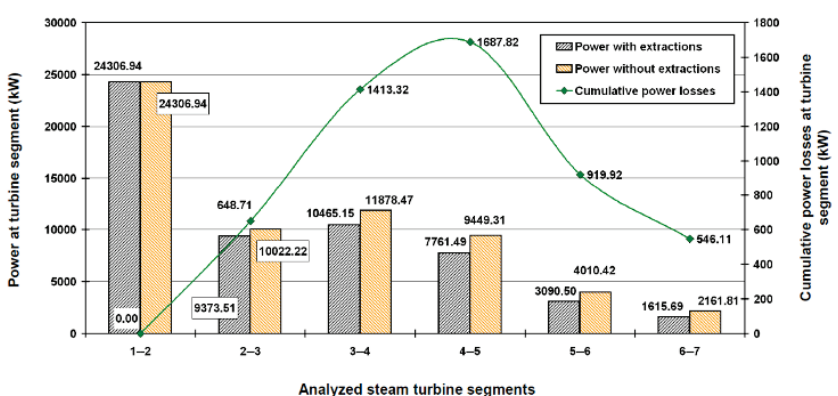

Figure 6 Developed power and cumulative power losses at each segment of the analyzed steam turbine

An extracted steam mass flow rate, which has a dominant influence on power losses in each turbine segment is the first extracted steam mass flow rate $\left(\dot{m}_{2}\right)$. In the second turbine segment (2--3), the first extracted steam mass flow rate $\left(\dot{m}_{2}\right)$ is the only component which defines cumulative power losses, Fig. 7, while in the other turbine segments sum of at least two extracted steam mass flow rates defines cumulative power losses. In the last turbine segment, all of the extracted steam mass flow rates define cumulative power losses.

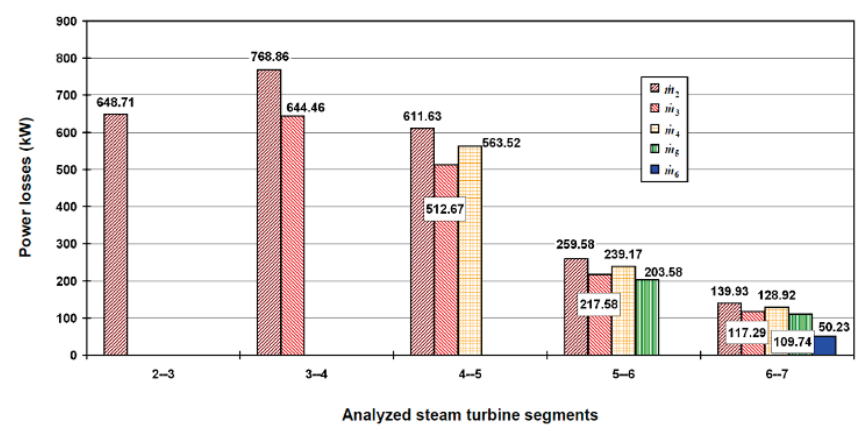

Figure 7 Distribution of power losses at each analyzed turbine segment due to steam mass flow rate extractions

Further research, reduction of power losses and possible optimization of the steam turbine analyzed in this paper will be performed by using various artificial intelligence methods [57-61].

\section{CONCLUSIONS}

This paper presents an investigation of two possible steam turbine operation regimes - a regime with all steam extractions opened (base process) and a regime with all steam extractions closed. Major conclusions obtained from this analysis are as follows:

- Closing of all steam extractions significantly increases turbine real developed power in comparison to the regime when all steam extractions are opened (from $56613.29 \mathrm{~kW}$ to $61829.17 \mathrm{~kW}$ ).

- All steam turbine extractions closing, in comparison to the regime when all steam extractions are opened, significantly increases turbine energy and exergy losses (from $23736.46 \mathrm{~kW}$ to $28638.19 \mathrm{~kW}$ for energy losses and from $20361.77 \mathrm{~kW}$ to $25109.87 \mathrm{~kW}$ for exergy losses).

- Closing of all steam turbine extractions decreases turbine energy and exergy efficiencies when compared to the base process when all steam extractions are opened (from $70.46 \%$ to $68.34 \%$ for energy efficiency and from $73.55 \%$ to $71.12 \%$ for exergy efficiency).

- First extracted steam mass flow rate has a dominant influence on turbine power losses (in comparison to maximum turbine power without steam extractions).

- Analyzed turbine develops the highest power (24306.94 $\mathrm{kW}$ ) in its first segment.

- Cumulative power losses caused by steam mass flow rate extractions are the highest in the fourth turbine segment and equal to $1687.82 \mathrm{~kW}$ (in comparison to the turbine regime when all of the extractions are closed).

\section{Acknowledgments}

This research has been supported by the Croatian Science Foundation under the project IP-2018-01-3739, CEEPUS network CIII-HR-0108, European Regional Development Fund under the grant KK.01.1.1.01.0009 (DATACROSS), project CEKOM under the grant KK.01.2.2.03.0004, CEI project "COVIDAi" (305.6019-20), University of Rijeka scientific grant uniri-tehnic-18-2751447 and University of Rijeka scientific grant uniri-tehnic18-18-1146.

\section{NOMENCLATURE}

Latin symbols:

ex specific exergy, $\mathrm{kJ} / \mathrm{kg}$

$\dot{E} \quad$ fluid flow power, $\mathrm{kW}$

$h \quad$ specific enthalpy, $\mathrm{kJ} / \mathrm{kg}$

$\dot{m} \quad$ mass flow rate, $\mathrm{kg} / \mathrm{s}$

$p \quad$ pressure, $\mathrm{MPa}$

$P \quad$ power, $\mathrm{kW}$

$s \quad$ specific entropy, $\mathrm{kJ} / \mathrm{kg} \cdot \mathrm{K}$

$T$ temperature, $\mathrm{K}$

Greek symbols:

$\eta \quad$ efficiency, $\%$

\section{Subscripts:}

$0 \quad$ ambient state

en energy

ex exergy

i operating point index

ID IDeal (isentropic)

RE REal (polytropic)

WOSE WithOut Steam Extractions

WSE With Steam Extractions 


\section{REFERENCES}

[1] Ahmadi, G. R. \& Toghraie, D. (2016). Energy and exergy analysis of Montazeri steam power plant in Iran. Renewable and Sustainable Energy Reviews, 56, 454-463. https://doi.org/10.1016/j.rser.2015.11.074

[2] Kumar, V., Pandya, B., \& Matawala, V. (2019). Thermodynamic studies and parametric effects on exergetic performance of a steam power plant. International Journal of Ambient Energy, 40 (1), 1-11.

https://doi.org/10.1080/01430750.2017.1354326

[3] Babaelahi, M., Mofidipour, E., \& Rafat, E. (2020). Combined Energy-Exergy-Control (CEEC) analysis and multi-objective optimization of parabolic trough solar collector powered steam power plant. Energy, 201, 117641. https://doi.org/10.1016/j.energy.2020.117641

[4] Koroglu, T. \& Sogut, O. S. (2018). Conventional and advanced exergy analyses of a marine steam power plant. Energy, 163, 392-403.

https://doi.org/10.1016/j.energy.2018.08.119

[5] Mrzljak, V., Poljak, I., \& Prpić-Oršić, J. (2019). Exergy analysis of the main propulsion steam turbine from marine propulsion plant. Brodogradnja: Teorija $i$ praksa brodogradnje i pomorske tehnike, 70(1), 59-77. https://doi.org/10.21278/brod70105

[6] Kostyuk, A. \& Frolov, V. (1988). Steam and gas turbines. Mir Publishers, Moscow.

[7] Taylor, D. A. (1998). Introduction to marine engineering. Elsevier Butterworth-Heinemann.

[8] Fernández, I. A., Gómez, M. R., Gómez, J. R., \& Insua, Á. B. (2017). Review of propulsion systems on LNG carriers. Renewable and Sustainable Energy Reviews, 67, 1395-1411. https://doi.org/10.1016/j.rser.2016.09.095

[9] Lorencin, I., Anđelić, N., Mrzljak, V., \& Car, Z. (2019). Genetic Algorithm Approach to Design of Multi-Layer Perceptron for Combined Cycle Power Plant Electrical Power Output Estimation. Energies, 12(22), 4352. https://doi.org/10.3390/en12224352

[10] Prakash, D., \& Singh, O. (2019). Thermo-economic study of combined cycle power plant with carbon capture and methanation. Journal of Cleaner Production, 231, 529-542. https://doi.org/10.1016/j.jclepro.2019.05.217

[11] Aliyu, M., AlQudaihi, A. B., Said, S. A. M., \& Habib, M. A. (2020). Energy, exergy and parametric analysis of a combined cycle power plant. Thermal Science and Engineering Progress, 15, 100450. https://doi.org/10.1016/j.tsep.2019.100450

[12] Burin, E. K., Vogel, T., Multhaupt, S., Thelen, A., Oeljeklaus, G., Gorner, K., \& Bazzo, E. (2016). Thermodynamic and economic evaluation of a solar aided sugarcane bagasse cogeneration power plant. Energy, 117, 416-428. https://doi.org/10.1016/j.energy.2016.06.071

[13] Ahmadi, G., Toghraie, D., \& Akbari, O. (2019). Energy, exergy and environmental (3E) analysis of the existing CHP system in a petrochemical plant. Renewable and Sustainable Energy Reviews, 99, 234-242. https://doi.org/10.1016/j.rser.2018.10.009

[14] Taheri, M. H., Mosaffa, A. H., \& Farshi, L. G. (2017). Energy, exergy and economic assessments of a novel integrated biomass based multigeneration energy system with hydrogen production and LNG regasification cycle. Energy, 125, 162177. https://doi.org/10.1016/j.energy.2017.02.124

[15] Yilmaz, F., Ozturk, M., \& Selbas, R. (2019). Design and thermodynamic analysis of coal-gasification assisted multigeneration system with hydrogen production and liquefaction. Energy Conversion and Management, 186, 229240. https://doi.org/10.1016/j.enconman.2019.02.053
[16] Mrzljak, V., Poljak, I., \& Mrakovčić, T. (2017). Energy and exergy analysis of the turbo-generators and steam turbine for the main feed water pump drive on LNG carrier. Energy conversion and management, 140, 307-323. https://doi.org/10.1016/j.enconman.2017.03.007

[17] Adibhatla, S. \& Kaushik, S. C. (2014). Energy and exergy analysis of a super critical thermal power plant at various load conditions under constant and pure sliding pressure operation. Applied thermal engineering, 73(1), 51-65. https://doi.org/10.1016/j.applthermaleng.2014.07.030

[18] Behrendt, C. \& Stoyanov, R. (2018). Operational Characteristic of Selected Marine Turbounits Powered by Steam from Auxiliary Oil-Fired Boilers. New Trends in Production Engineering, 1(1), 495-501. https://doi.org/10.2478/ntpe-2018-0061

[19] Ray, T. K., Datta, A., Gupta, A., \& Ganguly, R. (2010). Exergy-based performance analysis for proper O\&M decisions in a steam power plant. Energy Conversion and Management, 51(6), 1333-1344. https://doi.org/10.1016/j.enconman.2010.01.012

[20] Kowalczyk, T., Ziółkowski, P., \& Badur, J. (2015). Exergy losses in the Szewalski binary vapor cycle. Entropy, 17, 72427265. https://doi.org/10.3390/e17107242

[21] Sutton, I. (2015). Plant design and operations. Elsevier.

[22] Aljundi, I. H. (2009). Energy and exergy analysis of a steam power plant in Jordan. Applied thermal engineering, 29(2-3), 324-328. https://doi.org/10.1016/j.applthermaleng.2008.02.029

[23] Mitrović, D., Živković, D., \& Laković, M. S. (2010). Energy and exergy analysis of a $348.5 \mathrm{MW}$ steam power plant. Energy Sources, Part A, 32, 1016-1027. https://doi.org/10.1080/15567030903097012

[24] Mrzljak, V., Poljak, I., \& Medica-Viola, V. (2017). Dual fuel consumption and efficiency of marine steam generators for the propulsion of LNG carrier. Applied Thermal Engineering, 119, 331-346. https://doi.org/10.1016/j.applthermaleng.2017.03.078

[25] Hajebzadeh, H., Ansari, A. N. M., \& Niazi, S. (2019). Mathematical modeling and validation of a 320 MW tangentially fired boiler: A case study. Applied Thermal Engineering, 146, 232-242. https://doi.org/10.1016/j.applthermaleng.2018.09.102

[26] Mrzljak, V., Prpić-Oršić, J., \& Senčić, T. (2018). Change in steam generators main and auxiliary energy flow streams during the load increase of LNG carrier steam propulsion system. Pomorstvo, 32(1), 121-131. https://doi.org/10.31217/p.32.1.15

[27] Moran M., Shapiro H., Boettner, D. D., \& Bailey, M. B. (2011). Fundamentals of engineering thermodynamics. $7^{\text {th }}$ edition, John Wiley and Sons, Inc.

[28] Hoseinzadeh, S. \& Heyns, P. S. (2020). Thermo-structural fatigue and lifetime analysis of a heat exchanger as a feedwater heater in power plant. Engineering Failure Analysis, 113, 104548. https://doi.org/10.1016/j.engfailanal.2020.104548

[29] Kakac, S., Liu, H., \& Pramuanjaroenkij, A. (2012). Heat exchangers - selection, rating, and thermal design. $3^{\text {rd }}$ edition, CRC Press, Taylor \& Francis Group.

[30] Mrzljak, V., Poljak, I., \& Medica-Viola, V. (2017). Thermodynamical analysis of high-pressure feed water heater in steam propulsion system during exploitation. Brodogradnja: Teorija i praksa brodogradnje i pomorske tehnike, 68(2), 4561. https://doi.org/10.21278/brod68204

[31] Naserabad, S. N., Mehrpanahi, A., \& Ahmadi, G. (2019). Multi-objective optimization of feed-water heater arrangement options in a steam power plant repowering. Journal of Cleaner Production, 220, 253-270. https://doi.org/10.1016/j.jclepro.2019.02.125 
[32] Laskowski, R. (2016). Relations for steam power plant condenser performance in off-design conditions in the function of inlet parameters and those relevant in reference conditions. Applied Thermal Engineering, 103, 528-536. https://doi.org/10.1016/j.applthermaleng.2016.04.127

[33] Pattanayak, L., Padhi, B. N., \& Kodamasingh, B. (2019). Thermal performance assessment of steam surface condenser. Case Studies in Thermal Engineering, 14, 100484. https://doi.org/10.1016/j.csite.2019.100484

[34] Medica-Viola, V., Pavković, B., \& Mrzljak, V. (2018). Numerical model for on-condition monitoring of condenser in coal-fired power plants. International Journal of Heat and Mass Transfer, 117, 912-923. https://doi.org/10.1016/j.jijheatmasstransfer.2017.10.047

[35] Škopac, L., Medica-Viola, V., \& Mrzljak, V. (2020). Selection Maps of Explicit Colebrook Approximations according to Calculation Time and Precision. Heat Transfer Engineering, 115. https://doi.org/10.1080/01457632.2020.1744248

[36] Zhang, X., Li, Y., \& Chen, H. (2019). Performance assessment of air-cooled steam condenser with guide vane cascade. Journal of Thermal Science, 28 (5), 993-1003. https://doi.org/10.1007/s11630-019-1116-6

[37] Davies III, W. A., \& Hrnjak, P. (2019). Thermo-hydraulic model for steam condensation in a large, inclined, flattenedtube air-cooled condenser. Applied Thermal Engineering, 149, 745-756. https://doi.org/10.1016/j.applthermaleng.2018.12.050

[38] Noroozian, A., Mohammadi, A., Bidi, M., \& Ahmadi, M. H. (2017). Energy, exergy and economic analyses of a novel system to recover waste heat and water in steam power plants. Energy conversion and management, 144, 351-360. https://doi.org/10.1016/j.enconman.2017.04.067

[39] Kumar, S., Kumar, D., Memon, R. A., Wassan, M. A., \& Ali, M. S. (2018). Energy and exergy analysis of a coal fired power plant. Mehran University Research Journal of Engineering \& Technology, 37 (4), 611-624.

https://doi.org/10.22581/muet1982.1804.13

[40] Adibhatla, S., \& Kaushik, S. C. (2017). Energy, exergy, economic and environmental (4E) analyses of a conceptual solar aided coal fired $500 \mathrm{MWe}$ thermal power plant with thermal energy storage option. Sustainable Energy Technologies and Assessments, 21, 89-99. https://doi.org/10.1016/j.seta.2017.05.002

[41] Kocijel, L., Poljak, I., Mrzljak, V., \& Car, Z. (2020). Energy Loss Analysis at the Gland Seals of a Marine Turbo-Generator Steam Turbine. Tehnički glasnik, 14(1), 19-26. https://doi.org/10.31803/tg-20191031094436

[42] Zhao, Z., Su, S., Si, N., Hu, S., Wang, Y., Xu, J., ... \& Xiang, J. (2017). Exergy analysis of the turbine system in a $1000 \mathrm{MW}$ double reheat ultra-supercritical power plant. Energy, 119, 540-548. https://doi.org/10.1016/j.energy.2016.12.072

[43] Ibrahim, T. K., Basrawi, F., Awad, O. I., Abdullah, A. N., Najafi, G., Mamat, R., \& Hagos, F. Y. (2017). Thermal performance of gas turbine power plant based on exergy analysis. Applied Thermal Engineering, 115, 977-985. https://doi.org/10.1016/j.applthermaleng.2017.01.032

[44] Zhou, J., Ling, P., Su, S., Xu, J., Xu, K., Wang, Y., Hu, S., Zhu, M., \& Xiang, J. (2019). Exergy analysis of a 1000 MW single reheat advanced supercritical carbon dioxide coal-fired partial flow power plant. Fuel, 255, 115777. https://doi.org/10.1016/j.fuel.2019.115777

[45] Tontu, M., Sahin, B., \& Bilgili, M. (2019). Using energy and exergy analysis to compare different coal-fired power plants. Energy Sources, Part A: Recovery, Utilization, and Environmental Effects, 1-16. https://doi.org/10.1080/15567036.2019.1696429
[46] Mrzljak, V., \& Poljak, I. (2019). Energy Analysis of Main Propulsion Steam Turbine from Conventional LNG Carrier at Three Different Loads. NAŠE MORE: znanstveno-stručni časopis za more i pomorstvo, 66(1), 10-18. https://doi.org/10.17818/NM/2019/1.2

[47] Blažević, S., Mrzljak, V., Anđelić, N., \& Car, Z. (2019). Comparison of energy flow stream and isentropic method for steam turbine energy analysis. Acta Polytechnica, 59(2), 109125. https://doi.org/10.14311/AP.2019.59.0109

[48] Uysal, C., Kurt, H., \& Kwak, H. Y. (2017). Exergetic and thermoeconomic analyses of a coal-fired power plant. International Journal of Thermal Sciences, 117, 106-120. https://doi.org/10.1016/j.ijthermalsci.2017.03.010

[49] Kanoğlu, M., Çengel, Y.A., \& Dincer, I. (2012). Efficiency evaluation of energy systems. Springer Briefs in Energy, Springer.

[50] Lorencin, I., Anđelić, N., Mrzljak, V., \& Car, Z. (2019). Exergy analysis of marine steam turbine labyrinth (gland) seals. Pomorstvo, 33(1), 76-83. https://doi.org/10.31217/p.33.1.8

[51] Bühler, F., Van Nguyen, T., Kjær Jensen, J., Müller Holm, F., \& Elmegaard, B. (2018). Energy, exergy and advanced exergy analysis of a milk processing factory. Energy, 162, 576-592. https://doi.org/10.1016/j.energy.2018.08.029

[52] Tan, H., Shan, S., Nie, Y., \& Zhao, Q. (2018). A new boil-off gas re-liquefaction system for LNG carriers based on dual mixed refrigerant cycle. Cryogenics, 92, 84-92. https://doi.org/10.1016/j.cryogenics.2018.04.009

[53] Mrzljak, V., Blecich, P., Anđelić, N., \& Lorencin, I. (2019). Energy and Exergy Analyses of Forced Draft Fan for Marine Steam Propulsion System during Load Change. Journal of Marine Science and Engineering, 7(11), 381. https://doi.org/10.3390/jmse7110381

[54] Medica-Viola, V., Mrzljak, V., Anđelić, N., \& Jelić, M. (2020). Analysis of Low-Power Steam Turbine with One Extraction for Marine Applications. NAŠE MORE: znanstveni časopis za more i pomorstvo, 67(2), 87-95. https://doi.org/10.17818/NM/2020/2.1

[55] Erdem, H. H., Akkaya, A. V., Cetin, B., Dagdas, A., Sevilgen, S. H., Sahin, B., ... \& Atas, S. (2009). Comparative energetic and exergetic performance analyses for coal-fired thermal power plants in Turkey. International Journal of Thermal Sciences, 48(11), 2179-2186. https://doi.org/10.1016/j.jithermalsci.2009.03.007

[56] Lemmon, E. W., Huber, M. L., \& McLinden, M. O. (2010). NIST Standard Reference Database 23, Reference Fluid Thermodynamic and Transport Properties (REFPROP), version 9.0, National Institute of Standards and Technology. R1234yf. fld file dated December, 22, 2010.

[57] Lorencin, I., Anđelić, N., Mrzljak, V., \& Car, Z. (2019). Multilayer Perceptron approach to Condition-Based Maintenance of Marine CODLAG Propulsion System Components. Pomorstvo, 33(2), 181-190. https://doi.org/10.31217/p.33.2.8

[58] Baressi Šegota, S., Lorencin, I., Ohkura, K., \& Car, Z. (2019). On the Traveling Salesman Problem in Nautical Environments: An Evolutionary Computing Approach to Optimization of Tourist Route Paths in Medulin, Croatia. Pomorski zbornik, 57(1), 71-87. https://doi.org/10.18048/2019.57.05

[59] Naserbegi, A., Aghaie, M., Minuchehr, A., \& Alahyarizadeh, Gh. (2018). A novel exergy optimization of Bushehr nuclear power plant by gravitational search algorithm (GSA). Energy, 148, 373-385. https://doi.org/10.1016/j.energy.2018.01.119

[60] Baressi Šegota, S., Lorencin, I., Musulin, J., Štifanić, D., \& Car, Z. (2020). Frigate Speed Estimation Using CODLAG Propulsion System Parameters and Multilayer Perceptron. 
NAŠE MORE: znanstveni časopis za more i pomorstvo, 67(2), 117-125. https://doi.org/10.17818/NM/2020/2.4

[61] Lorencin, I., Anđelić, N., Mrzljak, V., \& Car, Z. (2019). Marine Objects Recognition Using Convolutional Neural Networks. NAŠE MORE: znanstveno-stručni časopis za more $i$ pomorstvo, 66(3), 112-119. https://doi.org/10.17818/NM/2019/3.3

\section{Authors' contacts:}

Vedran Mrzljak, PhD, Assistant Professor

(Corresponding author)

Faculty of Engineering, University of Rijeka,

Vukovarska 58, 51000 Rijeka, Croatia

E-mail: vedran.mrzljak@riteh.hr

Sandi Baressi Šegota, mag. ing. comp.

Faculty of Engineering, University of Rijeka,

Vukovarska 58, 51000 Rijeka, Croatia

E-mail: sbaressisegota@riteh.hr

Hrvoje Meštrić, $\mathrm{PhD}$

Catholic University of Croatia, University of Zagreb,

llica 242, 10000 Zagreb, Croatia

E-mail: hrvoje.mestric@unicath.hr

Zlatan Car, PhD, Full Professor

Faculty of Engineering, University of Rijeka,

Vukovarska 58, 51000 Rijeka, Croatia

E-mail: zlatan.car@riteh.hr 